\title{
Gallbladder Agenesis
}

\author{
Pashtoon Murtaza Kasi $i^{a, b} \quad$ Raymund Ramirez \\ Shari S. Rogal ${ }^{c} \quad K^{2}$ iley Littleton ${ }^{d}$ Kenneth E. Fasanella ${ }^{c}$ \\ ${ }^{a}$ International Scholars Program at ${ }^{b}$ Department of Internal Medicine, 'Division \\ of Gastroenterology, Hepatology and Nutrition, University of Pittsburgh \\ Medical Center (UPMC), and ${ }^{d}$ University of Pittsburgh, Pittsburgh, Pa., USA
}

\section{Key Words}

Gallbladder agenesis · Biliary colic · Conservative management · Sphincterotomy · Magnetic resonance cholangiopancreatography

\begin{abstract}
Gallbladder agenesis is a rare entity with an estimated incidence of 10-65 per 100,000. Females are more commonly affected (ratio 3:1), typically presenting in the 2nd or 3rd decade of life. Despite an absent gallbladder, half of patients present with symptoms similar to biliary colic, which is poorly understood. Clinicians should have a strong index of suspicion if nonvisualization is suggested by an ultrasound. HIDA scans are typically not helpful since nonvisualization of the gallbladder remains typical of cystic duct obstruction as well as of agenesis. While there are no specific guidelines for management of gallbladder agenesis, conservative management with smooth muscle relaxants is preferred. Sphincterotomy also has been reported in severe cases. Here, we report a case of a 21-year-old woman who presented with recurrent biliary colic and was diagnosed to have gallbladder agenesis on magnetic resonance cholangiopancreatography. A comparison with other cases and a review of the literature are presented.
\end{abstract}

\section{Introduction}

Gallbladder agenesis is a rare entity with an estimated incidence of 10-65 per 100,000 . Females are more commonly affected (ratio 3:1), typically presenting in the 2nd or 3rd decade of life. Despite an absent gallbladder, half of patients present with symptoms similar to biliary colic, which is poorly understood. Here, we report a case of a 21-year-old woman who presented with recurrent biliary colic and was diagnosed to have gallbladder agenesis on magnetic resonance cholangiopancreatography (MRCP). A comparison with other cases and a review of the literature are presented. 


\section{Case Presentation}

A 21-year-old woman presented to the hospital with right upper quadrant pain. She was in her usual state of health until 6 weeks prior when she developed abdominal pain. The pain was located in her right upper quadrant, dull, aching in quality, sudden in onset, colicky in nature, and radiated to her right scapula. Associated symptoms included nausea, vomiting, and inability to tolerate anything by mouth. These symptoms were worsened by meals and particularly by fatty food. The episodes of pain would last for 45-90 min following each meal. As a consequence of the post-prandial pain, she developed sitophobia and lost 12 pounds over a 6-week period.

Her past medical history was notable for a benign ovarian cyst. She had no prior surgical history. She was taking oral contraceptive pills and had no known drug allergies. Her social history was notable for lack of tobacco, alcohol or illicit drug use. With respect to her family history, both her parents had had cholecystectomies; her father at the age of 45 due to gallstone disease and her mother at the age of 39 (noted to have cholesterolosis). Family history was also significant for hemochromatosis in her father; her mother had not been tested.

The patient presented to the emergency department 4 weeks after symptom onset and given concerns for the biliary nature of her pain, she was evaluated by the surgical service. She had an ultrasound of her abdomen which showed prominence of her common bile duct (7 $\mathrm{mm}$ ) without intrahepatic biliary dilatation, and nonvisualization of her gallbladder. She subsequently underwent a HIDA scan, which was read as concerning for possible acute cholecystitis given the lack of gallbladder filling. She was discharged after symptomatic management with plans to be evaluated by gastrointestinal surgery for possible laparoscopic cholecystectomy in 4-6 weeks.

In the interim, she had recurrence of her symptoms and presented again to the emergency department. At this time, her exam revealed a nontoxic appearance with normal vital signs and mild tenderness to palpation in her right upper and bilateral lower quadrants without rebound or guarding. Her laboratory testing was notable for an unremarkable basic metabolic panel, CBC and liver enzymes. A CT scan was obtained and was read by the radiologist as 'status post cholecystectomy.' Given nonvisualization of the gallbladder on ultrasound as well as CT scan, an MRCP was ordered which revealed a 4-mm cystic lesion seen adjacent to the proximal common hepatic duct with apparent communication via a diminutive duct with the right hepatic duct, consistent with gallbladder agenesis/hypoplasia (fig. 1). At this point, a gastroenterology consult was called for assistance with further management.

\section{Discussion}

Gallbladder agenesis is a rare entity with an estimated incidence of 10-65 per $100,000[1,2]$. The incidence is noted to be higher (up to 90 per 100,000 ) in studies based on autopsy reports [3]. The first reports of cases of gallbladder agenesis date back to 1701 and 1702 by Lemery and Bergman [1, 2, 4]. The pathogenesis is related to embryonic development due to failure of the gallbladder and cystic duct to bud off from the common bile duct during the fifth week of gestation [1].

Table 1 summarizes a list of cases reported on gallbladder agenesis including the demographics of patients affected, their initial clinical presentation, mode of diagnosis and their outcomes. Females are more commonly affected (in a 3:1 ratio) and typically present in the 2 nd or 3 rd decade of life [5]. For unclear reasons, despite the absence of a gallbladder, up to $50 \%$ of patients present with symptoms similar to biliary colic [6]. Some postulate that an associated sphincter of Oddi dysfunction may be the cause of biliary colic in these patients [7]. In other cases, associated development of common bile duct stones may be the cause [2]. 
Prior authors have classified patients into three groups. The first group consists of asymptomatic anatomical abnormalities seen incidentally on autopsy. The second group presents with symptoms of biliary colic (54\%), dyspepsia (34\%) and/or jaundice $(27 \%)$, and the third presents in childhood with other associated severe fetal anomalies $[2,4]$.

The exact prevalence of each of the three groups is variable based on published reports. It is thought that approximately $70 \%$ of cases are usually isolated anomalies, although some cases appear to be familial and are associated with more severe anomalies [5, 8, 9]. In an interesting series of 34 cases ( 29 children and 5 adults) of congenital gallbladder agenesis, the most common anomalies associated were involving the genitourinary tract followed by gastrointestinal and cardiovascular malformations. Family history was negative in all, suggesting a sporadic occurrence [10].

Historically, all cases were identified intraoperatively. In a review of 9 cases by Cho et al. [11], all patients underwent a laparotomy, which failed to identify the gallbladder. However, now with the increased frequency of advanced imaging, cases are being diagnosed more often and, more importantly, before any surgical intervention.

However, given that patients with gallbladder agenesis tend to present symptoms suggestive of biliary colic, a number of them are still diagnosed intraoperatively. Due to a lack of awareness of the diagnosis, this entity remains a diagnostic challenge $[2,12]$. In those cases which are diagnosed intraoperatively, patients often are exposed to complications from prolonged exploration [13], and it is suggested to abort the procedure rather than complete further exploration if a gallbladder is not found on laparoscopy since open exploration for possible ectopic gallbladder increases the risk of complications [14]. Intraoperative ultrasound can demonstrate an ectopic gallbladder but is not always available [13]. A follow-up with more advanced imaging techniques should be the next option to truly identify gallbladder agenesis as the sole abnormality to guide management further.

It is therefore important to consider the presence of this unusual entity when the nonvisualization of the gallbladder is suggested on ultrasound [15]. However, as is known, ultrasound is highly dependent not only on the operator but also on other factors such as body habitus or presence of bowel gas obscuring visualization. Cases of gallbladder agenesis have been reported as 'contracted/fibrotic gallbladder' on ultrasound [14].

HIDA scans, which are also usually performed in patients with cholecystitis, in this case are unhelpful since nonvisualization of the gallbladder remains typical of cystic duct obstruction, as well as of agenesis [13, 16-18].

MRCP is considered the test of choice if there is suspicion. It is also helpful in demonstrating an ectopic gallbladder along with other possible anomalies of the biliary tract system $[8,19]$.

In terms of treatment, there are no specific guidelines on how to manage these cases. An algorithm published by Malde [2] is presented in figure 2. Interestingly, one author notes that $98 \%$ of patients had resolution of symptoms after exploratory, nontherapeutic surgery [5]. It is unclear how these patients would have had symptom 
resolution in the absence of exploration. This was also noted to be the case in 2 cases reported by Waisberg et al. [20] and some of the other reports (see table 1).

In this case, the patient was started on hyoscyamine extended release tablets twice daily, which did help alleviate her symptoms and has prevented any recurrence of symptoms or hospitalization during a 5-month follow-up.

She was also noted to be heterozygous for C282Y mutation for hereditary hemochromatosis. Whether the gene for gallbladder development is associated with hemochromatosis is not known, and we did not come across studies associating it with gallbladder agenesis.

\section{Conclusions}

Gallbladder agenesis presents as a significant diagnostic challenge. With the advances in imaging, more cases of gallbladder agenesis are being diagnosed incidentally and outside of the operating room. Clinicians should have a strong index of suspicion if nonvisualization is suggested by an ultrasound. A positive HIDA scan can be seen in the presence of gallbladder agenesis in the absence of cholecystitis. MRCP is considered the test of choice if there is suspicion. It is also helpful in demonstrating an ectopic gallbladder along with other possible anomalies of the biliary tract system. Management is usually conservative with smooth muscle relaxants.

\section{Acknowledgements}

We are deeply indebted to the patient for allowing us to present her information as a case report. Special thanks to Dr. Sachin Malde [2] for giving us the permission to include the algorithm (ig. 2) in our paper. 
Table 1. Summary of cases reported on gallbladder agenesis and demographics of patients affected, their clinical presentation, mode of diagnosis and their outcomes

\begin{tabular}{|c|c|c|c|c|c|}
\hline & Paper & Case & Presentation & Diagnosis on & Management/comments \\
\hline 1 & $\begin{array}{l}\text { Mittal } \\
\text { et al. [1] }\end{array}$ & $\begin{array}{l}45 \text {-year-old } \\
\text { woman }\end{array}$ & $\begin{array}{l}\text { Biliary colic/ } \\
\text { choledocholithiasis }\end{array}$ & CT/laparotomy & $\begin{array}{l}\text { Choledocholithotomy with } \\
\text { choledochoduodenostomy }\end{array}$ \\
\hline 2 & $\begin{array}{l}\text { Malde } \\
{[2]}\end{array}$ & 79-year-old man & $\begin{array}{l}\text { Choledocholithiasis/ } \\
\text { fatty food } \\
\text { intolerance/weight } \\
\text { loss }\end{array}$ & Laparotomy & $\begin{array}{l}\text { Open CBD exploration and } \\
\text { removal of CBD stones }\end{array}$ \\
\hline 3 & $\begin{array}{l}\text { Stephenson } \\
\text { et al. [5] }\end{array}$ & $\begin{array}{l}23 \text {-year-old } \\
\text { woman }\end{array}$ & Biliary colic & Laparotomy & $\begin{array}{l}\text { Interestingly revealed hepatic } \\
\text { hemangiomas mimicking as } \\
\text { gallstones. No intervention }\end{array}$ \\
\hline 4 & $\begin{array}{l}\text { Fiaschetti } \\
\text { et al. [8] }\end{array}$ & 44-year-old man & $\begin{array}{l}\text { Abdominal pain/ } \\
\text { dyspepsia }\end{array}$ & MRCP & $\begin{array}{l}\text { Conservative management; } \\
\text { clinical history revealed familial } \\
\text { gallbladder agenesis in two } \\
\text { paternal aunts during } \\
\text { laparoscopic surgery }\end{array}$ \\
\hline 5 & $\begin{array}{l}\text { Gupta } \\
\text { et al. [12] }\end{array}$ & $\begin{array}{l}28 \text {-year-old } \\
\text { woman }\end{array}$ & $\begin{array}{l}\text { Abdominal pain/ } \\
\text { dyspepsia }\end{array}$ & Laparotomy & Conservative management \\
\hline 6 & $\begin{array}{l}\text { Demir } \\
\text { et al. [9] }\end{array}$ & 47-year-old man & $\begin{array}{l}\text { Biliary } \\
\text { colic/dyspepsia }\end{array}$ & MRI/MRCP & $\begin{array}{l}\text { Conservative management; } \\
\text { associated congenital short and } \\
\text { annular pancreas, and splenic } \\
\text { malrotation were also noted }\end{array}$ \\
\hline 7 & $\begin{array}{l}\text { Balakrishnan } \\
\text { et al. [14] }\end{array}$ & $\begin{array}{l}\text { 30-year-old } \\
\text { woman }\end{array}$ & $\begin{array}{l}\text { Biliary } \\
\text { colic/dyspepsia }\end{array}$ & Laparoscopy & Conservative management \\
\hline 8 & $\begin{array}{l}\text { Balakrishnan } \\
\text { et al. [14] }\end{array}$ & 55-year-old man & $\begin{array}{l}\text { Admitted for } \\
\text { splenomegaly }\end{array}$ & CTA/ERCP & $\begin{array}{l}\text { Noted to have other associated } \\
\text { biliary anomalies and portal } \\
\text { vein thrombosis; management } \\
\text { not reported in detail }\end{array}$ \\
\hline 9 & $\begin{array}{l}\text { Peloponissios } \\
\text { et al. [13] }\end{array}$ & 34-year-old man & $\begin{array}{l}\text { Abdominal pain/ } \\
\text { bloating }\end{array}$ & $\begin{array}{l}\text { Laparoscopy } \\
\text { converted to } \\
\text { laparotomy }\end{array}$ & $\begin{array}{l}\text { A branch of the right hepatic } \\
\text { duct was also noted to have } \\
\text { been injured. The segmental } \\
\text { biliary duct was ligated and the } \\
\text { area drained }\end{array}$ \\
\hline 10 & $\begin{array}{l}\text { Peloponissios } \\
\text { et al. [13] }\end{array}$ & 76-year-old man & $\begin{array}{l}\text { Presentation was for } \\
\text { a renal tumor }\end{array}$ & CT/laparotomy & $\begin{array}{l}\text { In place of the gallbladder, a } \\
\text { small fibrous structure was } \\
\text { found and excised. Right } \\
\text { nephrectomy was also done at } \\
\text { the same time }\end{array}$ \\
\hline 11 & $\begin{array}{l}\text { Waisberg } \\
\text { et al. [20] }\end{array}$ & 68-year-old man & $\begin{array}{l}\text { Colicky abdominal } \\
\text { pain for } 10 \text { years }\end{array}$ & Laparotomy & $\begin{array}{l}\text { Was operated upon, but no } \\
\text { intervention done; patient } \\
\text { remains asymptomatic }\end{array}$ \\
\hline 12 & $\begin{array}{l}\text { Waisberg } \\
\text { et al. [20] }\end{array}$ & $\begin{array}{l}50 \text {-year-old } \\
\text { woman }\end{array}$ & Biliary colic & Laparoscopy & $\begin{array}{l}\text { Was operated upon, but no } \\
\text { intervention done; patient } \\
\text { remains asymptomatic }\end{array}$ \\
\hline 13 & $\begin{array}{l}\text { Vijay } \\
\text { et al. [17] }\end{array}$ & $\begin{array}{l}\text { 50-year-old } \\
\text { woman }\end{array}$ & $\begin{array}{l}\text { Chronic right upper } \\
\text { quadrant pain/ } \\
\text { dyspepsia }\end{array}$ & Laparotomy & $\begin{array}{l}\text { No intervention done } \\
\text { intraoperatively; associated } \\
\text { renal cysts noted }\end{array}$ \\
\hline
\end{tabular}




\begin{tabular}{|c|c|c|c|c|c|}
\hline 14 & $\begin{array}{l}\text { Cho } \\
\text { et al. [11] }\end{array}$ & $\begin{array}{l}9 \text { cases were } \\
\text { reviewed }\end{array}$ & $\begin{array}{l}\text { Jaundice noted in } 5 \text {, } \\
\text { epigastric pain in } 4 \text {, } \\
5 \text { had right upper } \\
\text { quadrant pain (1 had } \\
\text { symptoms typical for } \\
\text { a biliary colic) }\end{array}$ & $\begin{array}{l}\text { All cases underwent } \\
\text { laparotomy; in } \\
\text { only } 1 \text { case CT } \\
\text { had suggested } \\
\text { gallbladder agenesis }\end{array}$ & $\begin{array}{l}\text { Specific outcomes not stated in } \\
\text { the paper }\end{array}$ \\
\hline 15 & $\begin{array}{l}\text { Hershman } \\
\text { et al. [6] }\end{array}$ & 23-year-old man & $\begin{array}{l}\text { Recurrent biliary } \\
\text { colic }\end{array}$ & Laparoscopy & $\begin{array}{l}\text { No intervention done } \\
\text { intraoperatively; patient also } \\
\text { had Gilbert's disease }\end{array}$ \\
\hline 16 & $\begin{array}{l}\text { Dickinson } \\
\text { et al. [18] }\end{array}$ & 69-year-old man & $\begin{array}{l}\text { Abdominal pain/ } \\
\text { dyspepsia }\end{array}$ & Laparotomy & $\begin{array}{l}\text { No intervention was done, } \\
\text { patient remained asymptomatic }\end{array}$ \\
\hline 17 & $\begin{array}{l}\text { Turkel } \\
\text { et al. [10] }\end{array}$ & $\begin{array}{l}\text { Necropsy study: } \\
34 \text { cases ( } 29 \\
\text { children and } 5 \\
\text { adults); of the } \\
\text { adults, } 4 \text { were } \\
\text { males and } 1 \text { was } \\
\text { female }\end{array}$ & - & - & - \\
\hline 18 & $\begin{array}{l}\text { Wright } \\
\text { et al. [7] }\end{array}$ & $\begin{array}{l}\text { 50-year-old } \\
\text { woman }\end{array}$ & Biliary colic & Laparotomy & $\begin{array}{l}\text { No intervention was done, } \\
\text { patient remained asymptomatic }\end{array}$ \\
\hline 19 & $\begin{array}{l}\text { Monroe } \\
\text { et al. [3] }\end{array}$ & 46-year-old man & Abdominal pain & $\begin{array}{l}\text { Patient was scheduled } \\
\text { for cholecystectomy; } \\
\text { diagnosis revealed on } \\
\text { autopsy }\end{array}$ & $\begin{array}{l}\text { Patient apparently died from } \\
\text { 'pulmonary problems' before he } \\
\text { was to be operated upon }\end{array}$ \\
\hline 20 & $\begin{array}{l}\text { Beuran } \\
\text { et al. [21] }\end{array}$ & $\begin{array}{l}23 \text {-year-old } \\
\text { woman }\end{array}$ & Biliary colic & Laparoscopy & $\begin{array}{l}\text { No intervention was done, } \\
\text { patient remained asymptomatic }\end{array}$ \\
\hline 21 & $\begin{array}{l}\text { Beuran } \\
\text { et al. [21] }\end{array}$ & $\begin{array}{l}\text { 52-year-old } \\
\text { woman }\end{array}$ & $\begin{array}{l}\text { Right upper quadrant } \\
\text { pain }\end{array}$ & Laparotomy & $\begin{array}{l}\text { No intervention was done, } \\
\text { patient remained asymptomatic }\end{array}$ \\
\hline 22 & $\begin{array}{l}\text { Ishida } \\
\text { et al. [22] }\end{array}$ & $\begin{array}{l}\text { 84-year-old } \\
\text { woman }\end{array}$ & $\begin{array}{l}\text { Abdominal pain/ } \\
\text { choledocholithiasis }\end{array}$ & Laparotomy & $\begin{array}{l}\text { Impacted stone removed; t-tube } \\
\text { placed }\end{array}$ \\
\hline 23 & $\begin{array}{l}\text { Gotohda } \\
\text { et al. [23] }\end{array}$ & 29-year-old man & $\begin{array}{l}\text { Right upper quadrant } \\
\text { pain/vomiting }\end{array}$ & Laparoscopy & $\begin{array}{l}\text { No intervention was done, } \\
\text { patient remained asymptomatic }\end{array}$ \\
\hline
\end{tabular}




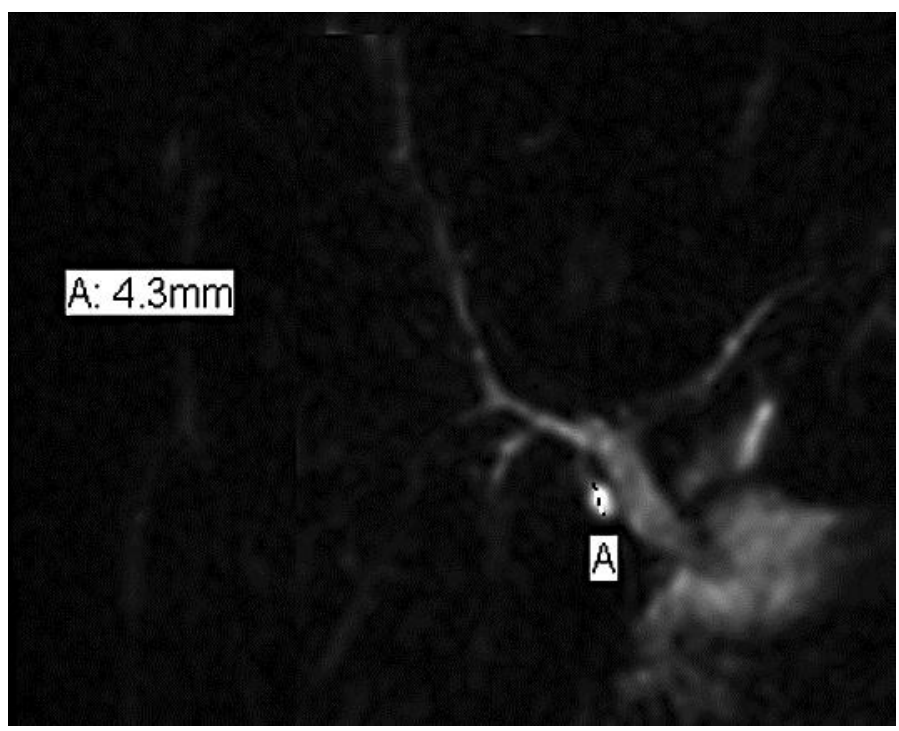

Fig. 1. MRCP showing a 4-mm cystic lesion adjacent to the proximal common hepatic duct with apparent communication through a tiny duct with the right hepatic duct, representing a hypoplastic gallbladder. MRCP is considered the test of choice if there is suspicion of a hypoplastic gallbladder. It is also helpful in demonstrating an ectopic gallbladder along with other possible anomalies of the biliary tract system. 


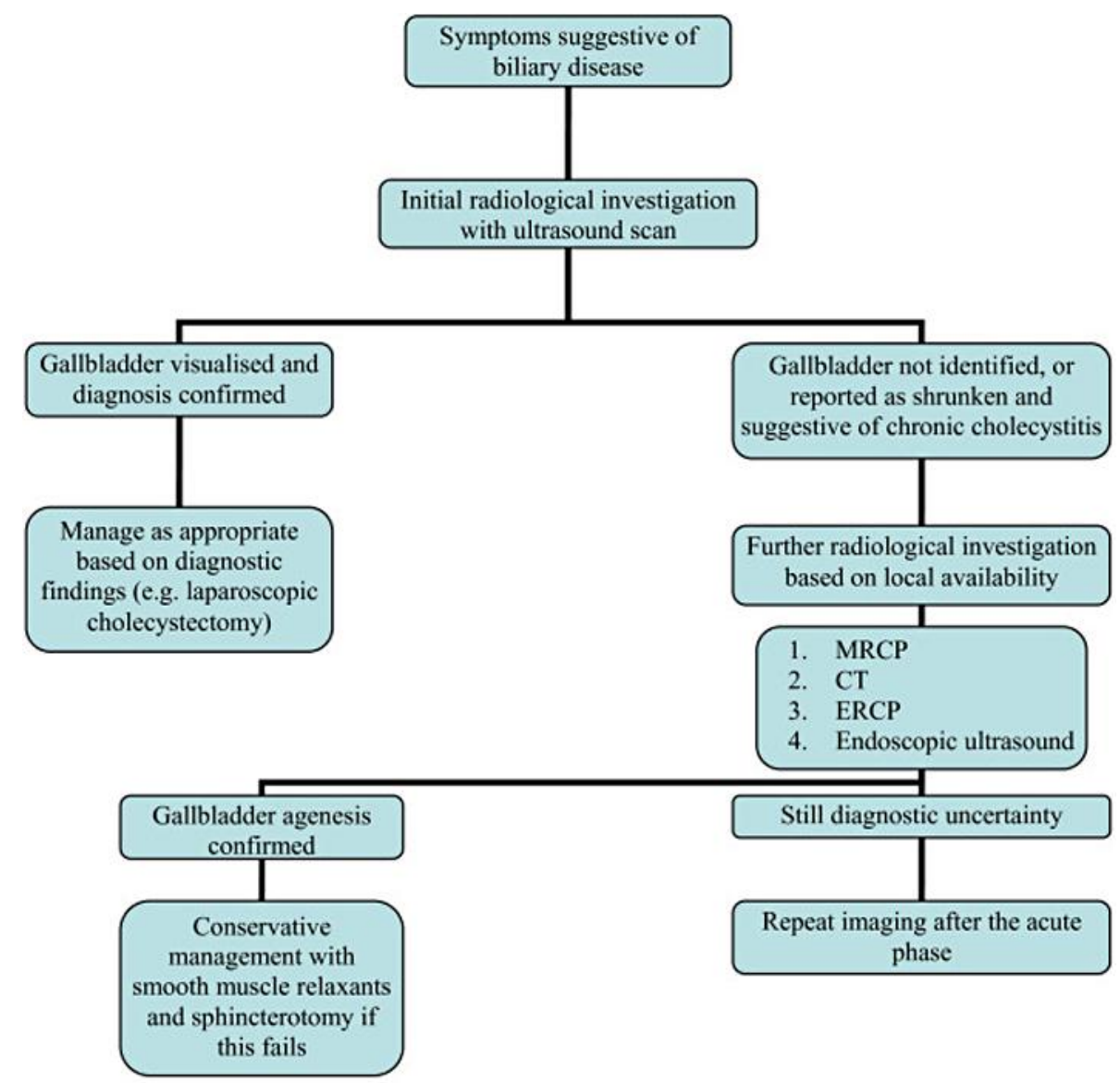

$\mathrm{MRCP}=$ magnetic resonance cholangiopancreatography

$\mathrm{ERCP}=$ endoscopic retrograde cholangiopancreatography

Fig. 2. Algorithm for workup and management of gallbladder agenesis as suggested by Malde [2]. As noted, while there are no specific guidelines for management of gallbladder agenesis, conservative management with smooth muscle relaxants is preferred. Sphincterotomy also has been reported in severe cases. (Permission to use under creative contributions open access license from http://www.biomedcentral.com; permission also obtained from the author.)

\section{References}

1 Mittal A, Singla S, Singal R, Mehta V: Gallbladder agenesis with common bile duct stone: a rare case with a brief review of the literature. Turk J Gastroenterol 2011;22:216-218.

-2 Malde S: Gallbladder agenesis diagnosed intra-operatively: a case report. J Med Case Reports 2010;4:285.

3 Monroe SE, Ragen FJ: Congenital absence of the gallbladder. Calif Med 1956;85:422-423.

-4 Bennion RS, Thompson JE, Tompkins RK: Agenesis of gallbladder without extrahepatic biliary atresia. Arch Surg 1988;123:1257-1260.

5 Stephenson JA, Norwood M, Al-Leswas D, Al-Taan O, Beable R, Lloyd DM, Dennison AR: Hepatic haemangioma masquerading as the gallbladder in a case of gallbladder agenesis: a case report and literature review. HPB Surg 2010;2010. pii: 971609. 
6 Hershman MJ, Southern SJ, Rosin RD: Gallbladder agenesis diagnosed at laparoscopy. J R Soc Med 1992;85:702-703.

7 Wright E, Madore P: Congenital absence of the gallbladder. Can Med Assoc J 1965;93:123-125.

8 Fiaschetti V, Calabrese G, Viarani S, Bazzocchi G, Simonetti G: Gallbladder agenesis and cystic duct absence in an adult patient diagnosed by magnetic resonance cholangiography: report of a case and review of the literature. Case Report Med 2009;2009:674768.

-9 Demir MK, Kilicoglu G: Rare coincidence of congenital short and annular pancreas with gallbladder agenesis and splenic malrotation. Br J Radiol 2008;81:e204-e206.

10 Turkel SB, Swanson V, Chandrasoma P: Malformations associated with congenital absence of the gall bladder. J Med Genet 1983;20:445-449.

11 Cho CH, Suh KW, Min JS, Kim CK: Congenital absence of gallbladder. Yonsei Med J 1992;33:364-367.

12 Gupta N, Gupta SK, Kapoor HS: Gallbladder and cystic duct agenesis diagnosed laparoscopically. Hepatobiliary Pancreat Dis Int 2010;9:107-108.

13 Peloponissios N, Gillet M, Cavin R, Halkic N: Agenesis of the gallbladder: a dangerously misdiagnosed malformation. World J Gastroenterol 2005;11:6228-6231.

14 Balakrishnan S, Singhal T, Grandy-Smith S, El-Hasani S: Agenesis of the gallbladder: lessons to learn. JSLS 2006;10:517-519.

15 Kabiri H, Domingo OH, Tzarnas CD: Agenesis of the gallbladder. Curr Surg 2006;63:104-106.

16 Gad MA, Krishnamurthy GT, Glowniak JV: Identification and differentiation of congenital gallbladder abnormality by quantitative technetium-99m IDA cholescintigraphy. J Nucl Med 1992;33:431-434.

17 Vijay KT, Kocher HH, Koti RS, Bapat RD: Agenesis of gall bladder - a diagnostic dilemma. J Postgrad Med 1996;42:80-82.

18 Dickinson CZ, Powers TA, Sandler MP, Partain CL: Congenital absence of the gallbladder: another cause of false-positive hepatobiliary image. J Nucl Med 1984;25:70-72.

19 Fulcher AS, Turner MA, Capps GW: MR cholangiography: technical advances and clinical applications. Radiographics 1999;19:25-41; discussion 41-44.

20 Waisberg J, Pinto PE Jr, Gusson PR, Fasano PR, de Godoy AC: Agenesis of the gallbladder and cystic duct. Sao Paulo Med J 2002;120:192-194.

21 Beuran M, Păun S, Negoi I, Gănescu R, Runcanu A, Avram M, Chiotoroiu AL: Laparoscopic approach in gallbladder agenesis - an intraoperative surprise (in Romanian). Chirurgia (Bucur) 2010;105:531-536.

-22 Ishida M, Egawa S, Takahashi Y, Kohari M, Ohwada Y, Unno M: Gallbladder agenesis with a stone in the cystic duct bud. J Hepatobiliary Pancreat Surg 2008;15:220-223.

23 Gotohda N, Itano S, Horiki S, Endo A, Nakao A, Terada N, Tanaka N: Gallbladder agenesis with no other biliary tract abnormality: report of a case and review of the literature. J Hepatobiliary Pancreat Surg 2000;7:327-330. 